\title{
Strategic Human Resource Practice: A Systematic Framework and Causal Model of Learning Orientation, Quality of Leader-Member Exchange, Goal Orientation, and Workgroup Performance
}

\author{
Kijpokin Kasemsap \\ Suan Sunandha Rajabhat University, Bangkok, Thailand \\ kijpokinkasemsap@yahoo.com
}

\begin{abstract}
Research objectives were to determine a systematic framework and to blend a causal model of learning orientation, quality of leader-member exchange, goal orientation, and workgroup performance of pharmaceutical company employees in Thailand. The study reported the responses of 583 operational employees from 39 pharmaceutical companies operating in different parts of Thailand. Data were analyzed with descriptive statistics using SPSS (version 11.5) and path analysis using LISREL (version 8). Research findings indicated that dimensions of learning orientation, quality of leader-member exchange, and goal orientation have mediated positive effect on workgroup performance. Goal orientation positively mediates the relationships between learning orientation and workgroup performance and between quality of leader-member exchange and workgroup performance. Furthermore, learning orientation is positively correlated with the quality of leader-member exchange.
\end{abstract}

Keywords: Causal Model, Goal Orientation, Learning Orientation, Quality of Leader-Member Exchange, Workgroup Performance

\section{Introduction}

A learning organization exploits its knowledge resources to generate superior performance (Pemberton \& Stonehouse, 2000). From a strategic point of view, a firm will seek knowledge that is lacking and is vital for the fulfilment of its strategic objectives (Lindley \& Wheeler, 2000). The learning perspective has been seen as an investment with long-term rather than short-term outcomes, thus making difficult implementation of learning or knowledge development cultures within today's modern business environments where short-term strategies predominate (Garvin, 1993). The leadership quality concept based on leader-member exchange theory (LMX) is incorporated into the framework to identify the key leadership aspects that affect the formation of employees' learning and performance goal orientation (Graen et al., 1990). Research objectives were to determine a systematic framework and to blend a causal model of learning orientation, quality of leader-member exchange, goal orientation, and workgroup performance of pharmaceutical company employees in Thailand.

\section{Review of Literature}

Organizational learning takes place at two levels: the individual and organizational levels (Slater \& Narver, 1995). Duncan and Weiss (1978) defined organizational learning as the process where knowledge is communicated and distributed across the organization, being integrated into the strategic and managerial philosophy of the organization. In the same context, learning orientation is conceptualized as the effort to give rise to organizational values that influence the propensity of the firm to create and use knowledge (Sinkula et al., 1997). Learning orientation is a concept relevant to organizational knowledge creation and usage capabilities (Sinkula et al., 1997). Learning orientation expresses an organizational framework of values creating and sharing capability (Sinkula et al., 1997). Furthermore, learning orientation has impact on performance (Baker \& Sinkula, 1999; Calantone et al., 2002). Organizational learning raises quality, strengthens customer and supplier relations, eases implementation of business strategies, and provides sustainable profitability (Mills \& Freisen, 1992). Firms implementing strong learning orientation policies, require employees to continuously question organizational norms, values, and practices that guide their organizational activities. Three organizational values are associated with the predisposition of organizations to learn (i.e., commitment to learning, open-mindedness, and shared vision) (Day, 1994; Tobin, 1993). Commitment to learning concerns the value placed on learning activities within an organization and the extent to which this value is viewed as axiomatic for the firm (Senge, 1990; Tobin, 1993). Galer and Van der Heijden (1992) stated that a culture amenable to learning is pre-requisite to improving its understanding of the environment over time. Openmindedness is related to the continuous proactive questioning of the firm's routines, assumptions, and beliefs (Senge, 1992; Sinkula, 1994). Shared vision provides an insight on the direction of learning 
orientation, a focus for learning how to foster energy, commitment and purpose among organizational members (Day, 1994). A significant area of research in organizational behavior focuses on the dyadic relationship between supervisors and subordinates (Dunegan et al., 1992; Wayne et al., 1997). Based on social exchange theory, and equity theory, the theoretical basis of the leader-member exchange (LMX) model provides an alternative approach to the study of leadership (Graen \& Scandura, 1987).

Leader-member exchange theory posits that leaders and members engage in a number of exchanges and interactions over time, thus affecting the development of the relationship between two parties involved (Sparrowe \& Liden, 1997). Drawing on social exchange theory, interpersonal relationships evolve between supervisors and subordinates, where both parties must offer something valuable to create an atmosphere of fairness and equity (Sparrowe \& Liden, 1997). Low-quality leader-member relationships form pure economic exchanges following contractual agreements, with supervisors obtaining routine subordinate performance and subordinates receiving standard organizational benefits (Graen et al., 1990; Yukl, 1994). High-quality leader-member relationships, on the other hand, form working exchanges characterized by mutual trust and support, with subordinates showing increased levels of commitment and competence and supervisors offering favorable rewards and promotions (Graen et al., 1990; Yukl, 1994). Psychological climate variables (i.e., autonomy, fairness, and group cohesion) are found to be influenced by reciprocal trust between managers and employees in terms of sales behavior and rewards (Strutton et al., 1993). Employees' job performance and job satisfaction depend on their goal orientations (Phillips \& Gully, 1997; Van Yperen \& Janssen, 2002). Goal orientations are believed to create different perceptual-cognitive frameworks for how individuals approach, interpret, and respond to achievable situations (Barron \& Harackiewicz, 2000; Duda, 2001; Dweck, 1999; Pintrich, 2000).

Goal orientations are viewed as rather stable personality characteristics fostered by "self-theories" about the nature and development of attributes (i.e., intelligence, personality, abilities, and skills) (Dweck, 1999). As such, a mastery goal orientation stems from the belief that one's attributes are dynamic and changeable and that exerting effort leads to performance improvement, while a performance goal orientation stems from the belief that attributes are fixed, concrete, and internal entities (Dweck, 1999). Performance-oriented individuals tend to believe that working hard does not lead to performance improvement. Working hard indicates low competence, and those who poorly perform do not have the attributes necessary to do well in their jobs (Dweck, 1999). A performance approach orientation is associated with superior performance (Barron \& Harackiewicz, 2000; Elliot \& Church, 1997; Harackiewicz et al., 1997). Performance- oriented employees tend to devote their attention to in-role job components that may help them to outperform others (Elliot \& McGregor, 2001). Leader-member exchange (LMX) theory and research suggested that the quality of the exchanges that develop between employees and their leaders are predictive of performance-related and attitudinal job outcomes, especially for employees (Gerstner \& Day, 1997; Graen \& Uhl-Bien, 1995). LMX theory is unique among leadership theories in its focus on the dyadic exchange relationships between supervisors and each of their subordinates (Gerstner \& Day, 1997).

The leader-member exchanges between mastery-oriented employees and their supervisors are likely to develop to high levels (Graen \& Uhl-Bien, 1995; Howell \& Hall-Merenda, 1999). Employees and supervisors can count on each other for support and loyalty, share important informational and behavioral resources, and base the exchange process on mutual trust, respect, and obligation (Graen \& Uhl-Bien, 1995; Howell \& Hall-Merenda, 1999). Leader-member exchanges are likely to be formal and impersonal and characterized by economic exchange behaviors and social-emotional distance between the exchange parties (Graen \& Uhl-Bien, 1995; Howell \& Hall-Merenda, 1999). A high quality of leadermember exchange is predictive of innovative job performance (Basu \& Green, 1997; Scott \& Bruce, 1994). LMX quality refers to the quality of the interpersonal exchange relationship between an employee and his or her supervisor (Graen \& Uhl-Bien, 1995). The quality of the relationships between leader and members determines the amount of physical or mental effort, material resources, information, and social support that are exchanged between leader and follower (Liden et al., 1997). DelVecchio (1998) stated that managerial latitude enhances LMX quality, increase subordinates' reliability, and transform employee into valued assets for managers (DelVecchio, 1998; Flaherty \& Pappas, 2000). To maximize workgroup performance, organizations must generate those values necessary to create a learning environment, focus on customers' needs, and create equally adaptive and generative learning opportunities (Baker \& Sinkula, 1999; Slater \& Narver, 1995).

Goal orientation has been typically defined as a property of the individual (Ames \& Archer, 1988; Dweck \& Leggett, 1988). The empirical and theoretical evidence suggests that situational factors impose a major 
influence on goal orientation as well (Ames \& Archer, 1988; Dweck \& Leggett, 1988). Social exchange theory is highly relevant to LMX research (Sparrowe \& Liden, 1997). Higher quality LMXs refer to relationships characterized by greater exchange of valued resources between members of the dyad including physical resources as well as information and attractive non-routine task assignments (Sparrowe \& Liden, 1997). The higher levels of learning orientation can produce an environment of greater trust and autonomy across all subordinates, resulting in higher quality LMXs (Sparrowe \& Liden, 1997). Supervisors engaging in higher quality LMX relationships will provide subordinates with added support, feedback, work-related resources and opportunities, thus forming strong exchange relationships and enhancing members' performance (Wayne et al., 1997). The higher quality LMX should be positively associated with productivity (Tanner \& Castleberry, 1990). Learning orientation will develop the knowledge, thus driving higher levels of performance (VandeWalle \& Cummings, 1997). Employees in high-quality LMX relationships make contributions that go beyond their formal job duties (Liden \& Graen, 1980). Similarly, employees working in lower quality relationships are expected not to perform beyond the formal employment contract (Bateman \& Organ, 1983).

\section{Methodology}

Data of this study were collected from 583 operational employees from 8,607 operational employees working in the 39 pharmaceutical companies in Thailand by using Yamane's formula (Yamane, 1970) for a $96 \%$ confidence level with a $4 \%$ margin of error by the proportional random sampling method. All the constructs were operationalized based on a seven-point Likert scale ranging from 1 (strongly disagree) to 7 (strongly agree). Data were analyzed with descriptive statistics using SPSS (version 11.5) and assessed with confirmatory factor analysis (CFA) to confirm the heterogeneity of all constructs and path analysis (Joreskog \& Sorborn, 1993) to detect the cause-effect relationships among various dimensions of main constructs of the study using LISREL (version 8) on a structured questionnaire containing standard scales of learning orientation, quality of leader-member exchange, goal orientation, and workgroup performance, besides some demographic details like age, education, and tenure with the organization. Learning orientation was measured using questionnaire developed by Sinkula et al. (1997) comprising three dimensions of commitment to learning, shared vision, and open-mindedness. Quality of leadermember exchange was measured using questionnaire developed by Liden and Graen (1980). Goal orientation was measured using questionnaire developed by Button et al. (1996). A sample item from the goal orientation was: "The things I enjoy the most are the things I do best." Workgroup performance was measured using questionnaire of three factors, namely team effectiveness (Gibson et al., 2003), workgroup cohesion, and interdependence (Wageman et al., 2005).

\section{Results and Discussion}

A systematic framework and a causal model were blended. Research findings indicated that dimensions of learning orientation, quality of leader-member exchange, and goal orientation have mediated positive effect on workgroup performance. Goal orientation positively mediates the relationships between learning orientation and workgroup performance and between quality of leader-member exchange and workgroup performance. Furthermore, learning orientation is positively correlated with the quality of leader-member exchange.

Figure 1: Systematic Framework and Causal Model.

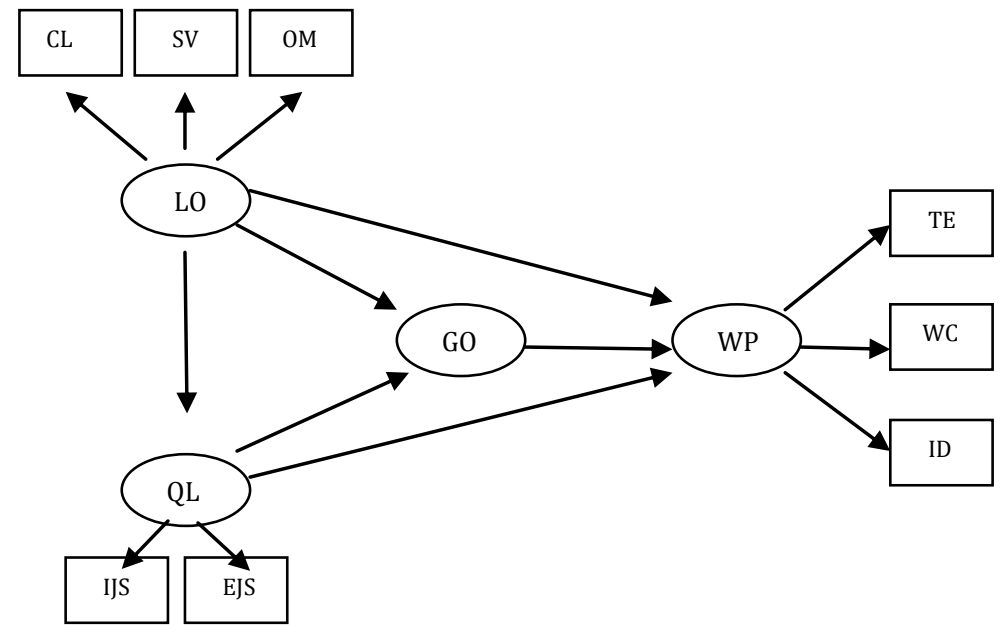


Key: $\mathrm{LO}=$ Learning Orientation, $\mathrm{CL}=$ Commitment to Learning, SV $=$ Shared Vision, OM = OpenMindedness, $\mathrm{QL}=$ Quality of Leader-Member Exchange, GO = Goal Orientation, $\mathrm{WP}=$ Workgroup Performance, $\mathrm{TE}=$ Team Effectiveness, $\mathrm{WC}=$ Workgroup Cohesion, $\mathrm{ID}=$ Interdependence

Regarding the systematic framework and causal model, there are lots of researchers studying the relationships of learning orientation, quality of leader-member exchange, goal orientation, and workgroup performance in a wide variety of fields. The systematic framework was positively compatible with the following research findings. Learning orientation, quality of leader-member exchange, and goal orientation are positively linked to workgroup performance. Modern firms need to facilitate the learning of all their members and build feedback loops so that there can be continuous strategy formation and improvement in the light of experience. Whichever learning practices are implemented, employees and managers need to work together and develop a consensus concerning stimulation to find new knowledge. It is very important for managers to have a clear learning orientation, which will create a learning atmosphere within the working environment. Learning orientation values must be clearly understood through organizational actions focusing on knowledge acquisition and sharing. The importance of learning orientation values lies on the creation of a learning philosophy pointing out the need for all employees of the business unit to seek ways of improving their performance by continually mastering their abilities, thus increasing their competitiveness. The primary contribution of the leader-member exchange theory to the proposed strategic learning pathway follows from its underlying aspect that managers differentiate in the quality of the exchange relationships. Managers that engage in exchanges with employees enhance employees 'learning desire driving improvements on skills that will lead to superior performance. Moreover, high quality leadership can directly influence employees' performance, create the feelings of obligation on the one hand and expectations of future returns on the other, and drive the interaction between individuals. Furthermore, high leadership quality can generate the desire to maximize rewards and minimize losses, thus transforming employees into valued assets for managers and organizations. It is very important for firms to focus on leadership styles that should not consider employees as winners or losers but potential discoverers while aiming at inspiring their organizational force to pursue a learning goal orientation (Sujan et al., 1994).

\section{Conclusion}

The purposes of this study were to determine a systematic framework and to blend a causal model of learning orientation, quality of leader-member exchange, goal orientation, and workgroup performance for pharmaceutical company employees in Thailand. The findings showed that the learning orientation, quality of leader-member exchange, and goal orientation have the strength to mediate positive effect on workgroup performance. In relation to the systematic framework and causal model, this result was the extent to which learning orientation, quality of leader-member exchange, and goal orientation have mediated positive effect on workgroup performance. Goal orientation positively mediates the relationships between learning orientation and workgroup performance and between quality of leadermember exchange and workgroup performance. Furthermore, learning orientation is positively correlated with the quality of leader-member exchange. Firms should pay special attentions to leadership style and organizational culture in which performance management practices are most likely to enhance organizational performance, and those in which such enhancement is less likely to occur. Firms may create the learning orientation and quality of leader-member exchange to encourage employees not only behave in interactive ways, but are also stimulated to improve goal orientation and workgroup performance and to manifest creative and innovative behaviors of employees. In addition, firms should recognize and shape leader-member exchange and goal orientation favorable to goal orientation and workgroup performance.

Recommendations: Potential cultural limitation should be noted and it is suggested that future research be done in different cultural contexts to generalize or modify the concepts. Furthermore, this study mainly concerns the effects of learning orientation and quality of leader-member exchange on goal orientation and workgroup performance. Future research may work on examining the impacts of other variables (i.e., career commitment, organizational citizenship behavior, organizational trust, job involvement, perceived organizational support, and employee engagement) on goal orientation, and workgroup performance. 


\section{References}

Ames, C. \& Archer, J. (1988). Achievement goals in the classroom: Students' learning strategies and processes. Journal of Educational Psychology, 80(3), 260-267.

Baker, W. E. \& Sinkula, J. M. (1999). The synergistic effect of market orientation and learning orientation on organizational performance. Journal of the Academy of Marketing Science, 27(4), 411-427.

Barron, K. E. \& Harackiewicz, J. M. (2000). Achievement goals and optimal motivation: A multiple goals approach. In C. Sansone \& J. Harackiewicz (Eds.). Intrinsic and Extrinsic Motivation: The Search for Optimal Motivation and Performance. San Diego: Academic Press.

Basu, R. \& Green, S. R. (1997). Leader-member exchange and transformational leadership: An empirical examination of innovative behaviors in leader-member dyads. Journal of Applied Social Psychology, 27(6), 477-499.

Bateman, T. S. \& Organ, D. W. (1983). Job satisfaction and the good soldier: The relationship between affect and employee citizenship. Academy of Management Journal, 26(4), 587-595.

Button, S. B., Mathieu, J. E. \& Zajac, D. M. (1996). Goal orientation in organizational research: A conceptual and empirical foundation. Organizational Behavior \& Human Decision Processes, 67(1), 26-48.

Calantone, R. J., Cavusgil, S. T. \& Zhao, Y. (2002). Learning orientation, firm innovation capability and firm performance. Industrial Marketing Management, 31(6), 515-524.

Day, G. (1994). The capabilities of market-driven organizations. Journal of Marketing, 58(4), 37-52.

DelVecchio, S. K. (1998). The quality of salesperson-manager relationship: The effect of latitude, loyalty and competence. Journal of Personal Selling and Sales Management, 18(1), 31-47.

Duda, J. L. (2001). Achievement goal research in sport: Pushing the boundaries and clarifying some misunderstandings. In G. Roberts (Ed.). Advances in Motivation in Sport and Exercise. Champaign: Human Kinetics Books.

Duncan, R. B. \& Weiss, A. (1978). Organizational learning: Implications for organizational design. In B. Staw (Ed.). Research in Organizational Behavior. Greenwich: JAI Press.

Dunegan, K. J., Duchon, D. \& Uhl-Bien, M. (1992). Examining the link between leader-member exchange and subordinate performance: The role of task analyzability and variety as moderators. Journal of Management, 18(1), 59-76.

Dweck, C. S. (1999). Self-theories: Their role in motivation, personality, and development. Ann Arbor: Psychology Press, Taylor \& Francis Group.

Dweck, C. S. \& Leggett, E. L. (1988). A social-cognitive approach to motivation and Personality. Psychology Review, 95(2), 256-273.

Elliot, A. J. \& Church, M. A. (1997). A hierarchical model of approach and avoidance achievement motivation. Journal of Personality and Social Psychology, 72(1), 218-232.

Elliot, A. J. \& McGregor, H. A. (2001). A 2 x 2 achievement goal framework. Journal of Personality and Social Psychology, 80(3), 501-519.

Flaherty, K. E. \& Pappas, J. M. (2000). The role of trust in salesperson-sales manager relationships. Journal of Personal Selling and Sales Management, 20(4), 271-278.

Galer, G. \& Van der Heijden, K. (1992). The learning organization: How planners create organizational learning. Marketing Intelligence and Planning, 10(6), 5-12.

Garvin, D. A. (1993). Building a learning organization. Harvard Business Review, 71(4), 78-91.

Gerstner, C. R. \& Day, D. V. (1997). Meta-analytic review of leader-member exchange theory: Correlates and construct issues. Journal of Applied Psychology, 82(6), 827-844.

Gibson, C. B., Zellmer-Bruhn, M. E. \& Schwab, D. P. (2003). Team effectiveness in multinational organizations: Evaluation across contexts. Group \& Organization Management, 28(4), 444-474.

Graen, G. B. \& Scandura, T. A. (1987). Toward a psychology of dyadic organizing. In L. Cummings \& B. Staw (Eds.). Research in Organizational Behavior. Greenwich: JAI Press.

Graen, G. B. \& Uhl-Bien, M. (1995). Relationship-based approach to leadership: Development of leader member exchange (LMX) theory of leadership over 25 years: Applying a multi-level multidomain perspective. Leadership Quarterly, 6(2), 219-247.

Graen, G. B., Wakabayashi, M., Graen, M. R. \& Graen, M. G. (1990). International generalizability of American hypotheses about Japanese management progress: A strong inference investigation. Leadership Quarterly, 1, 1-23.

Harackiewicz, J. M., Barron, K. E., Carter, S. M., Lehto, A. T. \& Elliot, A. J. (1997). Predictors and consequences of achievement goals in the college classroom: Maintaining interest and making the grade. Journal of Personality and Social Psychology, 73(6), 1284-1295. 
Howell, J. M. \& Hall-Merenda, K. E. (1999). The ties that bind: The impact of leader-member exchange, transformational and transactional leadership, and distance on predicting follower performance. Journal of Applied Psychology, 84(5), 680-694.

Joreskog, K. G. \& Sorbom, D. (1983). LISREL 8: User's Reference Guide. Chicago: Scientific Software International.

Liden, R. C. \& Graen, G. (1980). Generalizability of the vertical dyad linkage model of Leadership. Academy of Management Journal, 23(1), 451-465.

Liden, R. C., Sparrowe, R. T. \& Wayne, S. J. (1997). Leader-member exchange theory: The past and potential for the future. Research in Personnel and Human Resource Management, 15, 47-119.

Lindley, E. \& Wheeler, F. P. (2000). The learning square: Four domains that impact on Strategy. British Journal of Management, 11(4), 357-364.

Mills, D. O. \& Freisen, B. (1992). The learning organization. European Management Journal, 10(2), 146156.

Pemberton, J. D. \& Stonehouse, G. H. (2000). Organizational learning and knowledge assets - an essential partnership. The Learning Organization, 7(4), 184-193.

Phillips, J. M. \& Gully, S. M. (1997). Role of goal orientation, ability, need for achievement, and locus of control in the self-efficacy and goal-setting process. Journal of Applied Psychology, 82(5), 792802.

Pintrich, P. R. (2000). The role of goal orientation in self regulated learning. In M. Boekaerts, P. Pintrich, \& M. Zeidner (Eds.). Handbook of Self-Regulation. San Diego: Academic Press.

Scott, S. G. \& Bruce, R. A. (1994). Determinants of innovative behavior: A path model of individual innovation in the workplace. Academy of Management Journal, 37(3), 580-607.

Senge, P. M. (1990). The Fifth Discipline: The Art and Practice of the Learning Organization. New York: Doubleday Currency.

Senge, P. M. (1992). Mental models. Planning Review, 20(2), 4-10.

Sinkula, J. M. (1994). Market information processing and organizational learning. Journal of Marketing, 58(1), 35-45.

Sinkula, J. M., Baker, W. E. \& Noordewier, T. (1997). A framework for market-based organizational learning: Linking values, knowledge and behavior. Journal of the Academy of Marketing Science, 25(4), 305-318.

Slater, S. F. \& Narver, J. C. (1995). Market orientation and the learning organization. Journal of Marketing, 59(4), 63-74.

Sparrowe, R. T. \& Liden, R. C. (1997). Process and structure in leader-member exchange. Academy of Management Review, 22(2), 522-552.

Strutton, D., Pelton, L. E. \& Lumpkin, J. R. (1993). The relationship between psychological climate and salesperson-sales manager trust in sales organizations. Journal of Personal Selling and Sales Management, 13(3), 1-14.

Sujan, H., Weitz, B. A. \& Kumar, N. (1994). Learning orientation, working smart and effective selling. Journal of Marketing, 58(3), 39-52.

Tanner, J. F. Jr. \& Castleberry, S. B. (1990). Vertical exchange quality and performance: Studying the role of the sales manager. Journal of Personal Selling and Sales Management, 10(2), 17-28.

Tobin, D. R. (1993). Re-Educating the Corporation: Foundations for the Learning Organization. Brattleboro: Oliver Wright.

VandeWalle, D. \& Cummings, L. I. (1997). A test of the influence of goal orientation on the feedback seeking process. Journal of Applied Psychology, 82(3), 390-400.

Van Yperen, N. W. \& Janssen, O. (2002). Feeling fatigued and dissatisfied or feeling fatigued but satisfied? Employees' goal orientations and their responses to high job demands. Academy of Management Journal, 45(6), 1161-1171.

Wageman, R., Hackman, J. R. \& Lehman, E. V. (2005). Team diagnostic survey: Development of an instrument. Journal of Applied Behavioral Science, 41(4), 373-398.

Wayne, S. J., Shore, L. M. \& Liden, R. C. (1997). Perceived organizational support and leader-member exchange: A social exchange perspective. Academy of Management Journal, 40(1), 82-111.

Yamane, T. (1970). Statistics - An Introductory Analysis. Tokyo: John Weatherhill.

Yukl, G. (1994). Leadership in Organizations. Englewood Cliffs: Prentice-Hall. 